\title{
Mindset Shift in Cyber Pedagogy: A Teacher's Strategy upon Learning from Home
}

\author{
Denny Kodrat ${ }^{1 *}$ \\ ${ }^{1}$ Sekolah Tinggi Bahasa Asing Sebelas April, Sumedang, Indonesia
}

\section{ARTICLE INFO}

\section{Keywords}

Cyber Pedagogy, Education,

Management, Mindset

\section{*Correspondence denny.kodrat@gmail.com}

\section{Article History}

Received 14 September 2020

Accepted 25 November 2020

Published online 30 November 2020

\section{ABSTRACT}

As Covid 19 pandemic hits Indonesia, teaching-learning activities change dramatically. Learning from home becomes the only alternative in conducting distance education. From the earlier, this cyber pedagogy is assumed as an emergency step taken by the government. Consequently, teachers hold the learning process without clear objectives. Many complaints have occurred, and some improvements are proceeded to reinvent the quality of education. As a radical response toward the chaotic situation, this article is aimed at investigating two significant issues. The first is the requirement of mindset shift as the way to solve the cyber pedagogical problem. The second is the teachers' strategy in doing online learning. Theories about distance learning and quality are referred to as library research does. A descriptive qualitative approach was carried out, and in-depth interviews with parents, students, and teachers were taken. The result of the discussion is the mindset shift in teachers, parents, and stakeholders is required. The creative teachers who have good literacy in information technology are needed in running e-learning and conduct interactive learning from home.

\section{INTRODUCTION}

Education in Indonesia dramatically changes when Covid 19 pandemic hits the country. A Minister of Education and Culture, Nadiem Anwar Makarim released a regulation no. 4/2020 about Learning Distance Implementation in Covid 19 Emergency Situation. The learning distance using a Learning Management System (LMS) is encouraged. The transformation of education is forced, and industry revolution 4.0 influences much education. In response to the Covid 19 situation, a school does not have any options but runs the activities using Information and Communication Technology (ICT). One of the distinguishing characteristics of industry revolution 4.0 is automation, artificial intelligence, and combining physical, digital, and biological worlds at the same time (Tjandrawinata, 2016). Furthermore, advanced technology is promoted, such as ICT, cyber-physical system, network communication, big data, cloud computing, modeling, visualization (Kinzel, 2012; Giannakos, 2010; Maison, 2007). ICT is used widely, as almost 80 percent of companies use ICT (Wahlster, 2012). The adequate infrastructure should be prepared by building useful internet broadband, while at the same time, the human resources, including teachers and students, are empowered. The gap generation happening between teachers and students is acknowledged. 2.097.319 teachers and staffs are from the baby boomer and Z generation (http://dashboardgtk.data.kemdikbud.go.id/ptk_usia.php?id=20). They were born from the 1960s to 1980s, while students are commonly millennials familiar with gadgets. This gap could become a potential problem to overcome when the government policy on education suggests using online service in teaching-learning activities (Silva, Costa, Prior, \& Rogerson, 2011; Surry, Ensminger, \& Haab, 2005).

The massive use of technology advocates students' 21st-century skills (Trilling \& Fadel, 2009; Hase \& Kenyon, 2007; Martin \& Webb, 2002). Life and career skills include (1) flexibility and adaptability; (2) initiative and self-direction; (3) social and crosscultural interaction; productivity and accountability, and (4) leadership and responsibility. Learning and innovation skills deal with (1) critical thinking and problem-solving; (2) communication and collaboration; (3). creativity and innovation (Silva, Rogerson, \& Stahl, 2010; Woodill, 2004; Kearsley, 2000; Yulistiana, 2020). Teachers can adapt and use software and applications to enhance students' competence. To promote collaboration, a teacher can use Padlet, TodaysMeet, Educlipper. To sharp the creativity, Google Draw, Canva, Pixlr Express are carried out. To develop critical thinking, Kidblog, Breakout EDU can be introduced. Google Classroom, Edmodo, Edulink, Microsoft Teams can be used as LMS. With a vigorous attempt and curiosity, a teacher can find applications on the internet, designing a challenging project in a virtual classroom. A growth mindset is set as the 
top priority for teachers (Kodrat, 2020) to start drowning in what is so-called "education 4.0" (Nusantara, 2018; Glazer, R. 1998; Omwenga, Waema, \& Wagacha, 2004; Harasim, Hiltz, Teles, \& Turoff, 1995).

In education 4.0, the students put themselves in reaching the outcome. The learning process is focused on the students' needs, not the teacher's needs. So, the student's center happens in the process. The students demonstrate and are responsible for what they have learned. Metacognitive is openly introduced. The teacher and school system only facilitate them to obtain the best achievement in a learning experience. Then, the learning process can be personalized and customized based on the students' characteristics. The platform, internet, learning sources, teachers, and students are unique entities completing a student, teacher, and stakeholder's needs. Gerstain (2014) states that learning principles in education 4.0 are: (1). Students decide what materials are going to learn and develop; (2). Students use learning and technology preferences to decide how they learn; (3). Students can create their learning community since many social media and other platforms are available; (4). Students can collaborate with experts; (5). Students can publish their learning experience by using social media and blog platforms; (5). Students can ask for feedback from whomever they wish, including their teachers, classmates, experts, or people worldwide.

This education 4.0 revolutionarily changes the learning habit that happened in the previous education. In education 1.0, education is viewed from a behavioristic perspective. 3 Rs are emphasized: (1). Receiving; (2). Responding; and (3). Regurgitating. In education 2.0, students take part. Constructivism is introduced, then the students can be more active and act as communicators, connectors, and collaborators. In education 3.0, the teacher's role becomes a facilitator, and the teacher attempts to use technology in doing the learning process (Gerstain, 2014). In the context of Islamic teachers, the adaptability towards changing situations is one of the positive cultures. Prophet Muhammad saw states that learning should also be performed by teachers, not students, as he says:

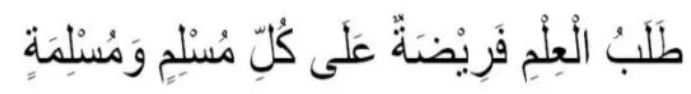

\section{Seeking knowledge is an obligation upon every Muslims (Sunan Ibnu Majah)}

Teachers, as Muslims, should keep learning to overcome future change. Including this current situation, learning from home using high technology probably causes potential problems that teachers should solve. This article tries to present two issues concerning learning from home. The first is the teacher's growth mindset and cyber pedagogy. The second is the Islamic teacher's strategy upon the cyber teaching-learning process. This manuscript is expected to open a new perspective that education quality is still regarded as necessary despite the online learning process. So, as the front line education service officer, teachers should think that the activity changes, but the objective stays the same. The service needs adjustment. However, it does not affect the indepth teaching material and the learning outcome.

Previous studies give insights into cyber pedagogy. Feenberg (1989) makes the differences between online and face-to-face discussion from a communication-theoretic perspective and highlights the specific communicative performances. Strong leadership on teaching-learning should be done in the meeting. He stated three functions of moderation in online learning. (1). Contextualizing functions; (2). Monitoring functions; and (3). Meta function. Berge (1995) gives a widely used into four categories: (1). Pedagogical; (2). Social; (3). Managerial; and (4). Technical. Anderson, Rourke, Garrison, \& Archer (2001) presents an evaluation model. This result is a considerable challenge. Online discussion is paradoxical. It consists of a flow of relatively disorganized improvisational exchanges that somehow achieve highly goal-directed, rational course agendas. Despite the apparent incoherence of online talk, participants have established norms that regain the coherence and personal character of conversational interaction (Costa \& Silva, 2010; Costa, G., Silva, \& Fonseca, 2012; Herring, 1996; Herring, 1999). Finally, a successful discussion generates intrinsic motivations to participate, which keep the discussion going. This framework is designed to bring out the complexity of online discussion and to provide a basis for advising teachers and evaluating applications and software

\section{RESEARCH METHODS}

This article was based on a literature study about cyber pedagogy and Islamic teachers' strategy upon learning from home. The analysis was done based on the facts collected from the literature, considering consistent facts found in the articles. A descriptive qualitative approach was carried out. To gather the data, in-depth interviews were performed with parents, students from grade XII and teachers in one of the prominent schools in Sumedang. The observation was conducted to keep the natural setting of the research's object. The conclusion was done based on these facts after the analysis was completed.

\section{RESULTS AND DISCUSSIONS}

From the depth interview conducted with parents and students, it is found that learning from home can run well if the instruction or learning objective is clear. "I cannot understand the instruction because the language used in the instruction is not clear, and there are many mistakes in typing or spelling," said an informant. The parent also said, "I buy an internet voucher for my daughter because she keeps asking about the subjects I cannot help. By buying the internet voucher, she can browse or ask her friends". From the interview, it is found that students seem to hesitate to ask their teachers. "I am shy to ask many questions to my teacher, while my friends also do not understand the material topic." The teachers seem to view that e-learning is only about tasks that should be done on time without any feedback. At the same time, the LMS is not used effectively since the discussion only uses social media.

The teacher's written communication ability has appeared when students state that they do not understand the instruction and explanation. Teachers should master logical ideas developed in written communication. In other words, teachers should keep writing and get used to generate their ideas in written form. The lack of writing skills can cause ambiguous instruction and explanation. The written communication should be evaluated, and if it becomes a barrier, then a school makes a

The teachers seem to be challenging to follow technology. The internet applications familiar to students are not used since the teachers do not understand how to operate them. They do not want to ask for their partners' bits of help since they believe their partners have similar duties. The short course or workshop does not give them ample space to ask and solve the problem. Another reason is the teachers are afraid of making a mistake in operating computers and internet applications. They prefer to teach in a classroom meeting rather than using LMS. 
The social media the teachers have are Whatsapp and Youtube. WhatsApp is used in giving tasks and distributes information, while Youtube is used to search for relevant information for student's materials. The teachers do not have a Youtube channel and do not know how to upload their Youtube videos. They only use a computer for typing in Microsoft Office, Powerpoint, and Microsoft Excell. They have a piece of limited information on how to operate computers for the Zoom meeting and Google meeting. However, they do not use the applications for learning activities since it spends internet credit much higher than Whatsapp.

\subsection{Engaging Student in Cyber Pedagogy}

Distance education has been a topic discussed and provided by educators (McVay \& Rockers, 2007; Ahmad, Basir, \& Hassanein 2004). E-learning with various platforms is introduced to schools and teachers. Internet transforms to be a support system for elearning. Then, e-learning is defined as using information technology to form a learning community, outcome, and experience (Ally, 2011; Horton, 2006). From the use of the internet and LMS, the educators also perform the blended learning method, enabling students to attend both offline and online classrooms. The medium to deliver materials can be varied (online or offline). However, the essence of education does not change. Learning is a must and becomes the core of education.

Western countries frequently use e-learning and blended learning since the weather conditions make the educators and stakeholders open alternative in learning. Internet bandwidths become the main facilities at schools. The students' access to the internet is easy, and one of the learning lifestyles. Cyber pedagogy is comprehended and designed by teachers in delivering elearning since e-learning is not merely putting the assignment on the LMS and giving many tasks to students without making interaction, giving feedback, and facilitating students with a new learning experience (Silva, Costa, Prior, \& Rogerson, 2013; 0'Neil, F, \& Newbold, 2008). So, the teachers think hard to design challenging and interning learning packages. The lesson plan is also created, generating the course objective, topic, materials, teaching method, and evaluation. Consequently, the learning quality is measured, and continuous reflection can be maintained even though it uses online learning.

In Indonesia's context, the teachers' and stakeholder's mindsets towards cyber pedagogy are a little bit different. Cyber pedagogy is still approached from a teacher center perspective. Moreover, teachers post many assignments in LMS or social media, then students ask their parents to teach them. On the other hand, the stakeholder's mindset sees teachers do nothing because the learning activities are not observed as in the classroom does. Then the dispute between teachers, schools, parents, and stakeholder emerge.

Another problem is the availability of gadgets, internet vouchers, and adequate internet bandwidth. Strong internet signals cover not all regions. If an internet provider is available in the area, it does not mean the gadget has a minimum requirement to meet the LMS or social media application. Non-technical problem is encountered by teachers, students, and parents, including internet service, gadget availability, and internet voucher cost, distracting the learning process. At the same time, the student's center perspective on learning has not been understood by teachers. Then, the teachers have difficulty in designing the learning process.

To engage students in cyber pedagogy, teachers should shift the mindset on student's learning perspective. Constructivism views that students are the center of learning, while Indonesian teachers are influenced by behaviorism, which puts teachers as a learning center. The use of cyber pedagogy imposes the student center perspective and should prepare students as real independent learners. Moreover, building independent learners' sustainability is a significant concern for teachers, parents, and stakeholders. The government should evaluate education achievement in the teaching-learning process in terms of independent learner's objective. The shift mindset from the teacher center to the student center has significantly proceeded. By using a cyber, teachers should also make a lesson plan in which every learning activity stage is depicted and evaluated.

A comprehension of asynchronous and synchronous media is also urgently needed. The teachers combine both synchronous and asynchronous media in teaching. The interaction between students and teachers is maintained by using frequent video conferences or by giving feedback. The pedagogical competence is importantly required to assess the students' situation and needs and see the support system's capability to run the learning activities. Some schools in Indonesia, from primary and intermediate education, launch home visits and learning groups instead of doing full online activities. This policy is made based on the problem faced by teachers, parents, and students (Vygotsky, 1978; Dabbagh, 2005). In cyber pedagogy, students-teachers interactions are limited. However, the government closes the eyes to the teacher's problems and still keeps learning from home policy. This phenomenon can be solved if the shifting mindset towards cyber pedagogy is promoted.

\subsubsection{The Need for Growth Mindset}

The issues of mindset stay in two basic concepts, growth mindset and a fixed mindset. The fundamental difference is that the growth mindset is open and willing to learn. A fixed mindset is closed and tends to refuse feedback and something new (Dweck, 1999, Dweck, 2006; Mueller \& Dweck, 1998; Kodrat, 2020). Teachers who give service to students directly should have a growth mindset in responding to a fast and dynamic situation and needs. In education 4.0 and 21 st-century education profile, the teachers play a significant role in giving and facilitating students to obtain their learning experience. The tremendous change happens in education 4.0. Information and Communication Technology (ICT) is introduced and urged to apply in classrooms. Cyber facilities are distributed and supported by the government, but ICT is limited only to individual teachers. The gap generation occurs in teachers. The baby boomer, teachers who were born in the 1940s to 1960s, tends to avoid ICT use. Some teaching aids have been replaced since the 2000s. Overhead projector, tape recorders, or posters as teaching aids to make students understand the teaching materials are substituted gradually with LCD projector and multi-media aids operated by computers. When the internet is started widely, paper is no longer use. Paperless work is preferred. However, the baby boomer teachers are difficult to follow the changes.

Teachers from baby boomers reach 975.441 people. It is a significant number. Moreover, the growth mindset is proposed. The teacher training is imposed. However, the slow response towards ICT is not something new. The technology keeps changing quickly. In industry revolution 4.0, internet technology is combined with automation; the teachers should have a growth mindset to keep learning and surfing with the unpredicted changes. A growth mindset is a requirement for teachers who want to keep in touch with technology. Being open-minded and willing to learn should be the teacher's mindset. It anticipates the changes, realizing the complexity in the current situation. The growth mindset character is open to constructive feedback, keeps learning, and eager to explore something new. 
The way to generate a growth mindset is not easy. External motivation is not sufficient to generate a growth mindset. Reward and punishment award is an example of external motivation. It will not work effectively as regular supervision cannot be maintained. Even the comfort zone traps the baby boomer teachers. One of the comfort zone examples is a teacher license. The government should have applied the regulation about the teacher's certification. The teaching license could be withdrawn if the teachers cannot accomplish specific competencies. Then, the regular competence test can be held to assess the teacher's competence. This way is hoped to generate a growth mindset.

The teacher's awareness of learning is the most effective way to awaken a growth mindset. The passion for teaching needs learning and sharing. The mental block is reduced when a new technology comes to support and make life easy. Learning becomes an essential need. Technology is approached and followed every time. Therefore, there is no hole between the technology leap and baby boomers. The awareness is strengthened by reading time habits (Hase, 2009; Lera \& Mor, 2007). Teachers should spend enough time to read and write about and by using technology. Then, technology is an object being used for improving student learning experiences. The way to attract teacher's awareness of learning is a school leader's responsibility. The leader should facilitate teachers with a satisfying support system for improving their competence. The tasks given to teachers should be balanced by providing a comfortable facility for continuous improvements.

The government should also analyze the teacher's workload when the government asks teachers many works to docompared with Singapore where the teacher and student ratio is 1;11.6, while Indonesian teacher and student ratio are 1:29 with the teacher's problem's distribution. Administration tasks such as a lesson plan, evaluation sheets, and other paper works are reduced. However, the number of teachers at schools is limited when many teachers are retired. The recruitment process should consider the growth mindset, especially the teacher's competence in technology.

\subsubsection{Teachers and technology}

The issue about teachers and technology or with the internet becomes an endless topic to discuss. Even, it becomes one of the favorite debate motions, like the topic "Can internet replace a teacher?" or "can a robot becomes a teacher?" In Indonesia, distance learning is one of the great concerns of the government. Universitas Terbuka (Open University) and SMP/SMA/SMK Terbuka (Open Junior, Senior or Vocational school) are examples of distance learning. However, the institutions' customers are people who have a job or employees who have little time to attend in the classroom. Then, online meetings and blended learning are performed. Unfortunately, these activities are not commonly experienced by all students. Only those who attend Universitas Terbuka do. Today, all students at all levels of education experience it. Even though the teachers make a learning module or student's worksheet or general description of the subject, they still do not satisfy the teachers' explanations on social media or in LMS. The students' and teacher's discussion in the chat room is hugely different from the classroom. The human interaction and transfer of values do not exist in the educational platform. From this condition, it seems that the debate motion dealing with teacher and internet or robot is concluded that the teacher is irreplaceable.

However, advanced technology is not fully responded to well by teachers. They stay in a comfort zone where the learning activities are only running as a daily routine. The technology is not used as a supporting system in improving a learning experience. That is why the student center does not appear. School leaders are confused when learning from home should be applied as a technology cannot be operated very well by the teachers. The essential requirement of effective distant learning is that students should be independent learners, and teachers can design learning activities by combining their lesson plans with technology. The government should consider how long they can seriously create an independent learner. The indication is that the students know why they need to study and are curious to find new knowledge. In completing the students' curiosity, teachers benefit from technology from planning, delivering a lesson, and evaluating.

\subsubsection{Strategy upon Learning from Home}

Making students learn is an important purpose which should be thought by teachers. Simultaneously, learning design should be meaningful (Khan, 2001; Lukman \& Krajnc, 2012). The transfer of knowledge, skills, and values comes around. Even though learning is on the internet or using LMS, students still get in touch with teachers as if they were standing in front of the class. To present the student-teacher interaction, the learning activities should meet the stages as Fig. 1

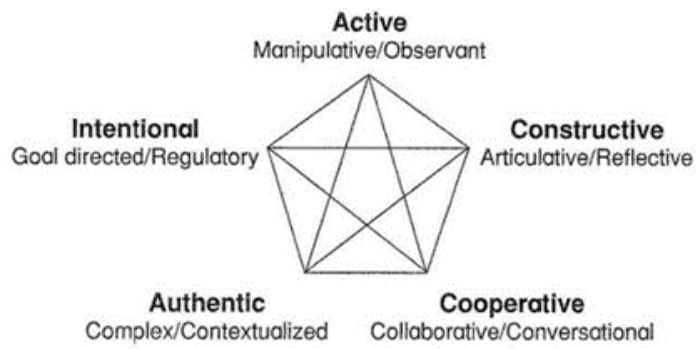

Figure 1. Meaningful Learning Process

Meaningful learning occurs when teachers determine a clear goal in learning, intentional goal-directed. In cyber pedagogy, the objective of learning activities should be stated clearly. Teachers should be active or even manipulative observant. The distance is not a barrier. The teacher should act as if they were there, sitting next to students. The learning activities are made constructive and reflective. Students know why they learn the topic or what competence they should have. The method still keeps cooperative, collaborative, and conversational activities. Students can engage with their friends even though they are separated. The topic should be presented in an authentic, complex, and contextualized way, so the students can think. The essence of learning is how to make students think-furthermore, three principles of effective cyber pedagogy. (1). Let the students do (most of) the work; (2) Interactivity is the heart and soul of effective asynchronous learning; (3). Strive for social, cognitive, and teaching presence.

To make meaningful learning, teachers should do the following advice. (1). Determine the content, pedagogy, and assessment; (2). Plan asynchronous-synchronous mix including video, non-video, and peer learning communities; (3). Explore opportunities 
specific to a course type (case-based, small group, or hands-on); (4). Decide for both asynchronous and synchronous instruction when and how the teachers will use or record video, engage directly with students, build community, and assess and gauge students' understanding.

\section{CONCLUSION}

The mindset shift in teachers, parents, and stakeholders is required in encouraging students to get involved in learning activities. Using LMS or technology at home in learning is not regarded as an emergency solution, but it becomes part of learning channels. Independent learners should be built earlier. The student center perspective is maintained, then the learning experience is facilitated by teachers while students can explore more other lessons that have not been discussed yet. Finally, creative teachers who have good literacy in information technology are needed in running cyber pedagogy and conduct interactive learning from home.

\section{ACKNOWLEDGEMENT}

This review never happens without a depth interview with teachers, parents from students of XII Social 5, SMA Negeri Jatinangor, Sumedang and the critical discussion with Suroto, S.S., M. Hum, Nurhasanah, S.S., M.Hum and Anit Pranita Devi, S.Pd., M.Pd (lecturers of STBA Sebelas April Sumedang) about distant learning and LMS applied in STBA Sebelas April Sumedang

\section{References}

Ahmad, A., Basir, O., \& Hassanein, K. (2004). Adaptive User Interfaces for Intelligent E-learning: Issues and Trends. In Proceedings of The Fourth International Conference on Electronic Business (ICEB 2004). Beijing.

Ally, M. (2011). Best Practices and Standards for e-Learning. Paper presented at 2nd International Conference on e-Learning and Distance Learning. Riyadh, Saudi Arabia.

Anderson, T., Rourke, L., Garrison, D.R. \& Archer, W. (2001) Assessing Teaching Presence in a Computer Conferencing Context, Journal of Asynchronous Learning Networks, 5(2).

Berge, Z.L. (1995) Facilitating Computer Conferencing: recommendations from the field, Educational Technology, 15(1), 22-30.

Costa, G., \& Silva, N. (2010). Knowledge versus content in e-learning: A philosophical discussion! Information Systems Frontiers, 12(4), 399-413.

Costa, G., Silva, N., \& Fonseca, T. (2012). Moral reasoning in knowledge authoring: an e-learning 4.0 analysis! In S. Abramovich (Ed.), Computers in Education-Volume 1 (pp. 135--154). Hauppauge, NY: Nova Science Publishers.

Dabbagh, N. (2005). Pedagogical models for e-learning: a theory based design framework, International Journal of Technology in Teaching and Learning, 1(1), 25-44.

Dweck, C. S. (1999). Self-Theories: Their Role in Motivation, Personality, and Development. Philadelphia, PA: Psychology Press.

Dweck, C. S. (2006). Mindset: The new psychology of success. New York, NY: Random House.

Feenberg, A. (1989) The Written World, in R. Mason \& A. Kaye (Eds) Mindweave: communication, computers, and distance education, 22-39. Oxford: Pergamon.

Gerstain, J. (2014). Moving from Education 1.0 Trough Education 2.0 Towards Education 3.0. Educational Technology Faculty Publications and Presentation. Department of Educational Technology.

Giannakos, M. (2010). The Evaluation of an E-learning Web-based Platform. In Proceedings of the 2nd International Conference on Computer Supported Education. CSEDU '10. INSTICC Press, 433-438.

Glazer, R. (1998). Measuring the knower: Towards a theory of knowledge equity. California Management Review, 40, 3, 75-94.

Harasim, L., Hiltz, S. R., Teles, L., \& Turoff, M. (1995). Learning Networks, A Field Guide to Teaching and Learning Online. Cambridge MA. The MIT Press.

Hase, S., \& Kenyon, C. (2007). Heutagogy: A child of complexity theory. Complicity: An International Journal of Complexity and Education, 4(1), 111-119.

Hase, S. (2009). Heutagogy and e-learning in the workplace: Some challenges and opportunities. Impact: Journal of Applied Research in Workplace E-learning, 1(1), 43-52.

Herring, S. (1996) Computer-mediated Communication: linguistic, social and cross-cultural perspectives. Amsterdam: John Benjamin.

Herring, S. (1999) Interactional Coherence in CMC, Journal of Computer-Mediated Communication, 4(4).

Horton, W. (2006). E-Learning by Design. Jhon Wiley\&Sons: Hoboken.

Kearsley, G. (2000). New Developments in Learning. http://home.sprynet.com/ gkearsley.

Khan, B. (2001). A framework for e_learning. Available at www. elearningmag.com/elearning/article/articleDetail.jsp?id=5163.

Kinzel, H. (2012). Industry 4.0: Where does this Leave the Human Factor? http://www.cujucr.com/downloads/Individual\%20Articles/15/vol15\%20Holger\%20Kinzel.pdf.

Kodrat, D. D. (2020). Growth Mindset of Quality Management in an Islamic School. Jurnal Kajian Peradaban Islam, 3(1), 22-26. https://doi.org/https://doi.org/10.47076/jkpis.v3i1.37

Lera, E., \& Mor, E. (2007). The joy of e-learning: redesigning the e-learning experience. Project PERSONAL (TIN 2006-15107- COZ01), Barcelona.

Lukman, R., \& Krajnc, M. (2012). Exploring Non-traditional Learning Methods in Virtual and Real-world Environments. International Forum of Educational \& Society (IFETS). Educational Technology \& Society, 15(1) 237--247.

Maison, K. B. (2007). A case for professional studies in education for teachers in higher educational institutions. In D. E. K. Amenumey (Ed.), Challenges of education in Ghana in the 21st century (pp. 248--256). Accra: Woeli Publishing Services.

Martin, E., \& Webb, D. (2002). Is E-learning good learning? The ethics and equity of e-learning in higher education (pp. 49--60). Melbourne: Victoria University: Equity and Social Justice.

McVay \& Rockers. (2007). Project Managing E-Learning: A Handbook for Successful Design, Delivery and Management. Routledge: Milton.

Mueller, C. M., \& Dweck, C. S. (1998). Praise for intelligence can undermine children's motivation and performance. Journal of personality and social psychology, 75(1), 33.

Nusantara, T. (2018). Desain Pembelajaran 4.0. Forum Seminar Nasional. Lembaga Penelitian Pendidik Mandala.

O'Neil, F, \& Newbold, (2008). Developing Online Learning Environments in Nursing Education. Springer Publishing Company: New York. 
Omwenga, E. I; Waema, T., \& Wagacha, P. W. (2004). A model for introducing and implementing e-learning for delivery of educational content within the African context, African Journal of Science and Technology, 5(1), 34-46.

Saunders, S. A. (2013). The Impact of a Growth Mindset Intervention on The Reading Achievement of At-Risk Adolescent Students. Ann Arbor, MI: ProQuest LLC.

Silva, N., Costa, G., Prior, M., \& Rogerson, S. (2013). The Evolution of E-learning Management Systems: An Ethical Approach. In Beycioglu (Ed.), Ethical Technology Use, Policy, and Reactions in Educational Settings (pp. 93--106). Hershey, PA: Information Science Reference. DOI=10.4018/978-1-4666-1882-4.ch008.

Silva, N., Costa, G., Prior, M., \& Rogerson, S. (2011). The evolution of E-learning Management Systems- an ethical approach. International Journal of Cyber Ethics in Education, 1, 3, 12--24.

Silva, N., Rogerson, S., \& Stahl, B. C. (2010). Ethicultural sensitivity in e-learning: discussing Lusíada Universities empirical findings. In Proceedings of the ETHICOMP 2010 (pp. 500--511). Tarragona. Spain.

Surry, D. W., Ensminger, D. C., \& Haab, M. (2005). A model for integrating instructional technology into higher education. British Journal of Educational Technology, 36, 2, 327--329. DOI=10.1111/j.1467-8535.2005.00461.x

Tjandrawinata. (2016). Industri 4.0: Revolusi Industri Abad ini dan Pengaruhnya pada Bidang Kesehatan dan Bioteknologi. Jurnal Medicinus, Vol 29, Nomor 1, Edisi April.

Trilling, B. \& Fadel, C. (2009). 21 $1^{\text {st }}$ Century Skills: Learning for Life Our Times. Jhon Wiley\&Sons: Hoboken.

Vygotsky, L. S. (1978). Mind in society. Cambridge: Harvard University Press.

Wahlster, W. (2012). Industry 4.0: From Smart Factories to Smart Products. https://pdfs.semanticscholar.org/ presentation/50d9/785fc35f33d42258b062b 27c77b8e36ec83c.pdf.

Woodill, G. (2004). Seven trends in corporate eLearning. White paper. Operitel Corporation. Available at www.operitel.com.

Yulistiana, A. (2020). Belajar Pendidikan Abad 21 di Queensland Australia. Diomedia: Sukoharjo. 